DOI: $10.15193 /$ zntj/2020/125/362

\author{
IZA BAJERLEIN, PATRYK BIELECKI
}

\title{
OKREŚLENIE PROFILU KWASÓW TEUSZCZOWYCH W WYCIĄGACH UZYSKANYCH ZA POMOCĄ EKSTRAKCJI DWUTLENKIEM WĘGLA W STANIE NADKRYTYCZNYM Z LIŚCI POKRZYWY ZWYCZAJNEJ (URTICA DIOICA L.)
}

\begin{abstract}
Streszczenie
Ekologiczne ekstrakty roślinne bogate w substancje biologicznie aktywne są cennym surowcem dla przemysłu spożywczego, stąd ciągle poszukuje się nowych ich źródeł. Szczególną uwagę zwraca się na rośliny pospolite, odporne na trudne warunki atmosferyczne, łatwo dostępne $\mathrm{i}$ tanie w uprawie. Do tego typu roślin należy pokrzywa zwyczajna (Urtica dioica L.). Celem pracy było określenie profilu kwasów tłuszczowych zawartych w liściach pokrzywy zwyczajnej, w wyciągach uzyskanych metodą ekstrakcji za pomocą nadkrytycznego dwutlenku węgla z dodatkiem etanolu. Uzyskano 5 ekstraktów różniących się sposobem pozyskania oraz parametrami procesu - czasem, ciśnieniem i temperaturą. Profil kwasów thuszczowych oznaczono metodą GC-MS. Identyfikację związków przeprowadzono na podstawie porównania widm masowych z biblioteką NIST 11 oraz porównania czasów retencji z certyfikowanym materiałem odniesienia. We wszystkich ekstraktach udział nienasyconych kwasów tłuszczowych był większy niż nasyconych kwasów tłuszczowych. W badaniach wykazano, że wzrost temperatury i ciśnienia procesu skutkował wyekstrahowaniem większej ilości pożądanych nienasyconych kwasów tłuszczowych. Największą zawartością nienasyconych kwasów tłuszczowych cechował się ekstrakt otrzymany w temp. $50{ }^{\circ} \mathrm{C}$ przy ciśnieniu 250 barów. W wyciągach uzyskanych przy zastosowaniu niskiego ciśnienia i wydłużonego czasu ekstrakcji nie zidentyfikowano kwasu eikozapentaenowego, który był obecny w pozostałych próbach.
\end{abstract}

Słowa kluczowe: pokrzywa zwyczajna, ekstrakcja nadkrytyczna, chromatografia gazowa, profil kwasów tłuszczowych

\section{Wprowadzenie}

Na przestrzeni ostatnich lat wzrosła świadomość konsumentów na temat zdrowego i racjonalnego odżywiania. Tendencję tę obserwuje się do chwili obecnej. Powszechny dostęp do informacji spowodował szersze zainteresowanie żywnością proz-

Mgr inż. I. Bajerlein, dr P. Bielecki, Fundacja Uniwersytetu im. A. Mickiewicza w Poznaniu, Poznański Park Naukowo-Technologiczny ul. Rubież46,61-612 Poznań. Kontakt: iza.bajerlein@ppnt.poznan.pl 
drowotną, zawierającą dodatki w postaci szczepów żywych kultur bakterii i związków biologicznie aktywnych, takich jak np. witaminy czy przeciwutleniacze oraz wzrost popytu na taką żywność $[10,15]$.

Do grupy substancji prozdrowotnych zalicza się związki syntetyzowane przez rośliny, które nie są niezbędne do prawidłowego ich funkcjonowania, czyli tzw. metabolity wtórne. Substancje te kumulowane w wakuoli są produktami ubocznymi w szlakach biosyntezy. Pierwotnym zadaniem wtórnych metabolitów roślinnych jest m.in. odstraszanie niepożądanych organizmów żerujących na danej roślinie (repelenty żywieniowe), osłabianie konkurentów pokarmowych (allelopatiny), przyciąganie organizmów symbiotycznych (chemoatraktanty). Związki te stanowi szeroka grupa niskocząsteczkowych substancji organicznych - szacuje się, że może być ich nawet dwa miliony, o różnym działaniu na organizm człowieka. Są to m.in. terpenoidy, alkaloidy, związki fenolowe, witaminy, czy niezbędne nienasycone kwasy thuszczowe (NNKT) [11]. W przemyśle spożywczym związki te stosowane są jako składniki produktów prozdrowotnych lub suplementów diety.

Do prozdrowotnych cech roślinnych metabolitów wtórnych należą m.in. właściwości grzybobójcze i bakteriobójcze, działania wspomagające w profilaktyce chorób takich, jak cukrzyca, nadciśnienie czy niektóre choroby nowotworowe. Szczególną rolę w profilaktyce chorób układu krążenia pełnią niezbędne nienasycone kwasy tłuszczowe (NNKT). Zalicza się je do grupy związków egzogennych, czyli takich, które organizm ludzki musi przyjmować z pożywieniem, gdyż nie jest w stanie ich samodzielnie syntetyzować $[10,11,15]$. NNKT wykazują korzystny wpływ na organizm ludzki. Wpływają m.in. na obniżanie ciśnienia tętniczego krwi, zapobieganie miażdżycy i zawałom serca oraz zwiększanie ogólnej odporności organizmu. Niezbędne nienasycone kwasy tłuszczowe występują głównie w rybach i owocach morza [1, 12, 14, 19], jak również w roślinach, w tym w nasionach lnu, słonecznika i rzepaku, w ziarnach soi, w pestkach dyni i winogron czy w orzechach $[1,5,20]$. W przypadku ryb oraz owoców morza problemem jest transport i długotrwałe przechowywanie tych produktów z zachowaniem cech świeżości i wartości odżywczej. W przypadku NNKT pochodzenia roślinnego wpływ na jakość oleju ma metoda jego pozyskiwania [21]. Tłoczenie jest odpowiednią metodą pozyskiwania oleju z roślin oleistych o dużej zawartości kwasów tłuszczowych, jednak nie jest efektywne w przypadku roślin z mniejszą ich zawartością. Z tego względu w niniejszej pracy zastosowano ekstrakcję za pomocą dwutlenku węgla w stanie nadkrytycznym do pozyskania kwasów tłuszczowych z liści pokrzywy zwyczajnej o znanych właściwościach prozdrowotnych $[2,4,6]$.

Pokrzywa zwyczajna (Urtica dioica L.) to wieloletnia roślina należąca do rodziny Urticaceae. Rozpowszechniona jest na obszarze Europy, Azji, Afryki Północnej i Ameryki Północnej. Ze względu na swoje właściwości jest szeroko stosowana w przemyśle spożywczym, farmaceutycznym i kosmetycznym. W medycynie ludowej 
używana jest do wspomagania leczenia stanów zapalnych i zakażeń bakteryjnych układu moczowego. Często stosuje się ją w kosmetyce, głównie jako składnik produktów do włosów. Wykorzystywana jest również jako roślina paszowa $[6,8,9]$. W ostatnich badaniach wskazuje się, że zastosowanie ekstraktów z pokrzywy na komórki rakowe prowadzi do zahamowania ich proliferacji [4]. Szerokie zastosowanie pokrzywy zwyczajnej wynika z naturalnego bogactwa jej składników. Przeprowadzono wiele badań mających na celu ustalenie składu chemicznego tej rośliny [2, 3, 9, 13]. Obecne są w niej m.in. witaminy z grupy B, C, E, K, flawonoidy, karotenoidy, polifenole, monoi oligosacharydy, a także wiele niezbędnych nienasyconych kwasów tłuszczowych [6, $8,9]$.

Coraz większy popyt na żywność funkcjonalną wymusił pojawienie się nowych metod pozyskiwania ekstraktów. Istnieje wiele sposobów ekstrakcji związków biologicznie aktywnych, w tym NNKT [17]. Na potrzeby tej pracy zastosowano ekstrakcję $\mathrm{z}$ wykorzystaniem dwutlenku węgla w stanie nadkrytycznym $\left(\mathrm{SFE}-\mathrm{CO}_{2}\right.$ Supercritical Fluid Extraction $-\mathrm{CO}_{2}$ ) i etanolu jako współrozpuszczalnika. Jest to stosunkowo nowy sposób ekstrakcji związków głównie pochodzenia roślinnego. W metodzie tej stosuje się dwutlenek węgla jako ekstrahent $\mathrm{w}$ warunkach temperatury i ciśnienia powyżej parametrów krytycznych tego gazu (temp. $31^{\circ} \mathrm{C}$, ciśnienie 71,8 bara). Zaletą tej technologii jest głównie bardzo małe oddziaływanie na środowisko - dwutlenek węgla po rozprężeniu i tym samym oddzieleniu od ekstrahowanej substancji może zostać zawrócony do układu i użyty ponownie, przez co redukowana jest jego emisja do atmosfery. Zmniejsza to jednocześnie koszty ekstrakcji. Dzięki zmianie głównych parametrów, takich jak temperatura i ciśnienie, można sterować procesem i ukierunkowywać go na ekstrakcję konkretnych grup związków. Równocześnie należy podkreślić, że otrzymany ekstrakt nie wymaga dalszej obróbki w postaci filtrowania czy wirowania i jest wolny od drobnoustrojów $[7,16,18]$.

Celem pracy było określenie profilu kwasów tłuszczowych zawartych w liściach pokrzywy zwyczajnej, w wyciągach uzyskanych metodą ekstrakcji za pomocą nadkrytycznego dwutlenku węgla $\mathrm{z}$ dodatkiem etanolu.

\section{Material i metody badań}

Materiał doświadczalny stanowił ekologiczny susz z liści pokrzywy zwyczajnej (Urtica dioica L.) - Dary Natury, który poddawano ekstrakcji nadkrytycznym dwutlenkiem węgla (99,995 \%, Air Liquide Polska Sp. z o.o.) i etanolem (96 \% cz.d.a., POCH, Polska) w stosunku $5: 1$. Parametry ekstrakcji regulowano w następującej kolejności: początkowo podczas doboru kierowano się tylko zmianą ciśnienia procesu (między 150 a 250 barów), następnie wydłużono czas trwania ekstrakcji, ostatecznie sprawdzono również wpływ podwyższenia temperatury o $10^{\circ} \mathrm{C}$. Każdorazowo do ekstrakcji odważano 1,5 g suszu (tab. 1). 
Tabela 1. Parametry procesu ekstrakcji

Table 1. Extraction proces parameters

\begin{tabular}{||c|c|c|c|c|c|c|c||}
\hline $\begin{array}{c}\text { Ekstrakt } \\
\text { Extract }\end{array}$ & $\begin{array}{c}\text { Temperatura } \\
\text { Temperature } \\
{\left[{ }^{\circ} \mathrm{C}\right]}\end{array}$ & $\begin{array}{c}\text { Ciśnienie } \\
\text { Pressure } \\
{[\text { bar }]}\end{array}$ & $\begin{array}{c}\text { Przepływ } \\
\mathrm{EtOH} \\
\text { EtOH } \\
\text { flow rate } \\
{[\mathrm{ml} / \mathrm{min}]}\end{array}$ & $\begin{array}{c}\text { Przepływ } \\
\mathrm{CO}_{2} \\
\mathrm{CO}_{2} \text { flow } \\
\text { rate } \\
{[\mathrm{ml} / \mathrm{min}]}\end{array}$ & $\begin{array}{c}\text { Faza } \\
\text { dynamiczna } \\
\text { Dynamic } \\
\text { phase } \\
{[\mathrm{min}]}\end{array}$ & $\begin{array}{c}\text { Faza sta- } \\
\text { tyczna } \\
\text { Static phase } \\
{[\mathrm{min}]}\end{array}$ & $\begin{array}{c}\text { Faza } \\
\text { dynamiczna } \\
\text { Dynamic } \\
\text { phase } \\
{[\mathrm{min}]}\end{array}$ \\
\hline 1 & 50 & 200 & 2 & 10 & 15 & 100 & 15 \\
\hline 2 & 50 & 150 & 2 & 10 & 15 & 100 & 15 \\
\hline 3 & 50 & 250 & 2 & 10 & 15 & 100 & 15 \\
\hline 4 & 50 & 250 & 2 & 10 & 25 & 240 & 25 \\
\hline 5 & 60 & 250 & 2 & 10 & 15 & 100 & 15 \\
\hline
\end{tabular}

Ekstrakty przechowywano w chłodziarce bez dostępu światła. Do wykonania oznaczenia profilu kwasów tłuszczowych pobierano $40 \mathrm{ml}$ każdego ekstraktu, który odparowywano w wyparce próżniowej Heidolph Hei-VAP Advantage 3G (Heidolph Instruments, Niemcy) aż do całkowitego usunięcia etanolu. Następnie rozpuszczano ekstrakt w $2 \mathrm{ml}$ dichlorometanu (do analizy pozostałości pestycydów GC, Chempur, Polska) i przenoszono $100 \mu \mathrm{l}$ roztworu do butelek z ciemnego szkła. Ekstrakty odparowywano do sucha $\mathrm{w}$ strumieniu azotu. W dalszej kolejności przeprowadzano derywatyzację kwasów tłuszczowych do estrów metylowych. W tym celu do każdej z pró-

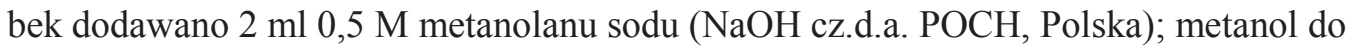
HPLC (Sigma-Aldrich, USA) i ogrzewano w temp. $80{ }^{\circ} \mathrm{C}$ przez $15 \mathrm{~min}$. Następnie dodawano $2 \mathrm{ml}$ trifluorku boru (14\%, Merck, Polska) i ogrzewano w temp. $80{ }^{\circ} \mathrm{C}$ przez $20 \mathrm{~min}$. Po schłodzeniu dodawano $2 \mathrm{ml}$ nasyconego roztworu chlorku sodu (cz.d.a. POCH, Polska) oraz $2 \mathrm{ml}$ heksanu (do chromatografii gazowej GC-MS, Merck, Polska). Po wytrząsaniu zbierano warstwę heksanową, filtrowano w obecności bezwodnego siarczanu magnezu (cz.d.a. POCH, Polska) przez filtr strzykawkowy PVDF $0,2 \mu \mathrm{m}$ (LLG Labware, Niemcy) i poddawano analizie.

Oznaczanie profilu kwasów tłuszczowych wykonywano metodą chromatografii gazowej. Metody przygotowania próbek oraz rozdziału chromatograficznego dobierano eksperymentalnie. Analizę prowadzono przy użyciu chromatografu gazowego Bruker 436-GC (Bruker Inc., USA) ze spektrometrem masowym SCION SQ z pułapką jonową i jonizacją elektronami (Shimadzu, Japonia). Stosowano kolumnę kapilarną WCOT Varian CP-sil 88 (Agilent Technologies Inc., USA) o długości 50 m, średnicy $0,25 \mathrm{~mm}$, filmem o grubości $0,20 \mu \mathrm{m}$ i z helem jako gazem nośnym. Identyfikację estrów metylowych kwasów tłuszczowych prowadzono dwutorowo: metodą porównania widm masowych z biblioteką NIST 11 oraz metodą porównania czasów retencji sygnałów chromatograficznych z certyfikowanym materiałem odniesienia (Supelco 37 component FAME mix, Sigma-Aldrich, USA). 


\section{Wyniki i ich omówienie}

Na rys. 1. przedstawiono przykładowy chromatogram profilu estrów metylowych kwasów tłuszczowych, z których dominującymi były estry metylowe kwasu palmity-

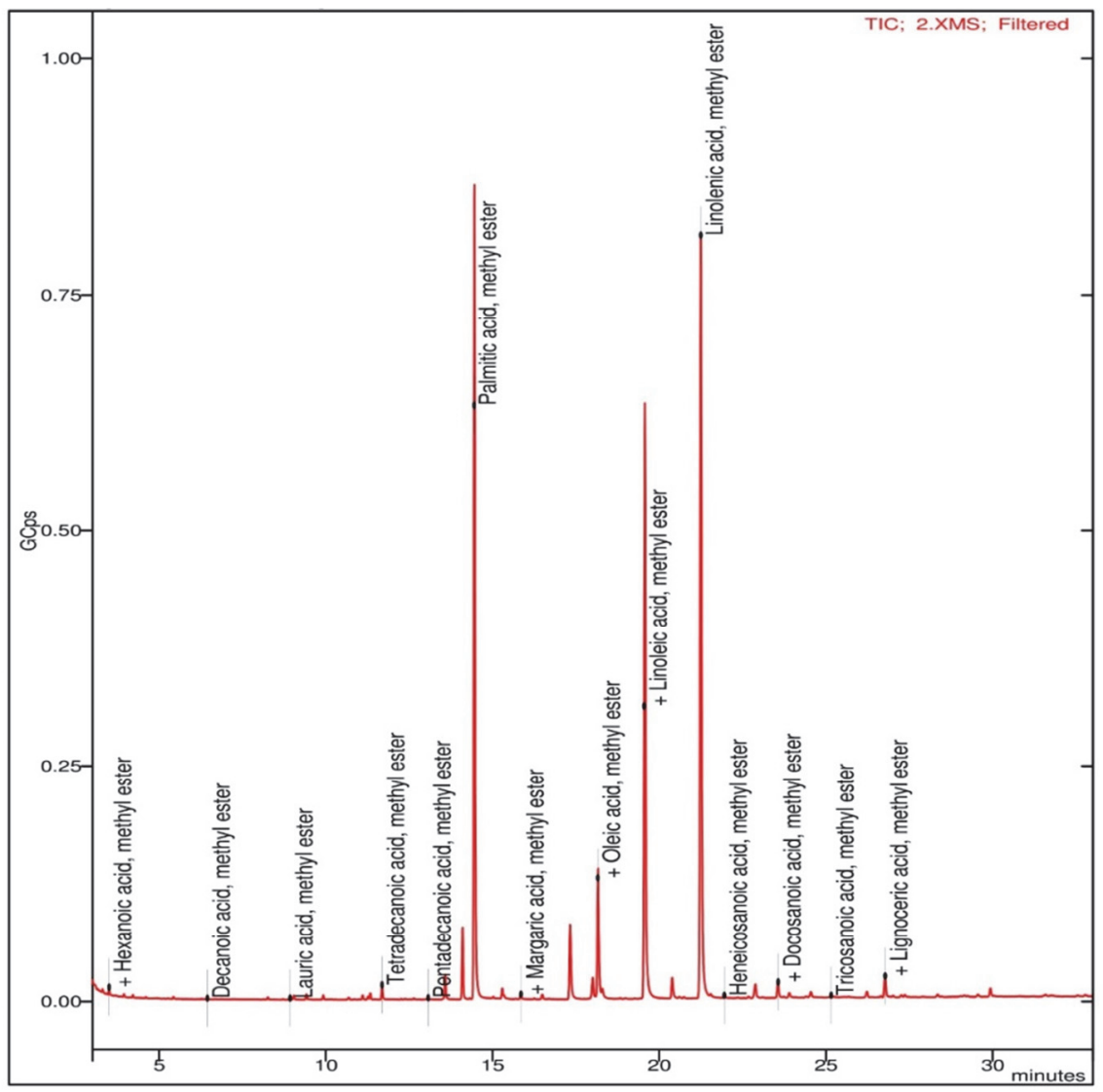

Objaśnienia / Explanatory notes:

hexanoic acid, methyl ester / ester metylowy kwasu kapronowego; decanoic acid, methyl ester / ester metylowy kwasu dekanowego; lauric acid, methyl ester / ester metylowy kwasu laurynowego; tetradecanoic acid, methyl ester / ester metylowy kwasu mirystynowego; pentadecanoic acid, methyl ester / ester metylowy kwasu pentadekanowego; palmitic acid, methyl ester / ester metylowy kwasu palmitynowego; margaric acid, methyl ester / ester metylowy kwasu margarynowego; oleic acid, methyl ester / ester metylowy kwasu oleinowego; linoleic acid, methyl ester / ester metylowy kwasu linolowego; linolenic acid, methyl ester / ester metylowy kwasu linolenowego; heneicosanoic acid, methyl ester / ester metylowy kwasu heneikozanowego; docosanoic acid, methyl ester / ester metylowy kwasu dokozanowego; tricosanoic acid, methyl ester / ester metylowy kwasu trikozanowego; lignoceric acid, methyl ester / ester metylowy kwasu lignocerowego.

Rys. 1. Chromatogram estrów metylowych kwasów tłuszczowych zawartych w ekstrakcie 2. z suszu liści pokrzywy

Fig. 1. Chromatogram of fatty acid methyl esters contained in extract 2 of dried nettle leaves 
nowego, linolowego i linolenowego. Zawartość oznaczonych estrów metylowych kwasów tłuszczowych w ekstraktach z suszu z liści pokrzywy przedstawiono w tab. 2.

We wszystkich ekstraktach występowały te same kwasy tłuszczowe (z wyjątkiem kwasu eikozapentaenowego w próbach 2 i 4). Wyekstrahowano zarówno kwasy tłuszczowe nasycone (SFA), kwasy thuszczowe nienasycone (UFA), w których skład wchodzą kwasy thuszczowe jednonienasycone (MUFA) oraz wielonienasycone kwasy thuszczowe (PUFA). Głównym kwasem nasyconym we wszystkich analizowanych ekstraktach był kwas palmitynowy. Wśród kwasów nienasyconych dominowały kwasy linolowy i $\alpha$-linolenowy. Próbki cechowały się również dużą zawartością kwasów: stearynowego, oleinowego, arachidowego i lignocerowego.

Tabela 2. Profil kwasów tłuszczowych w ekstraktach uzyskanych za pomocą SFE- $\mathrm{CO}_{2}$ z suszu liści pokrzywy

Table 2. Profile of fatty acids in extracts obtained by SFE- $\mathrm{CO}_{2}$ from dried nettle leaves

\begin{tabular}{|c|c|c|c|c|c|}
\hline \multirow{2}{*}{$\begin{array}{l}\text { Nazwa kwasu } \\
\text { Name of acid }\end{array}$} & \multicolumn{5}{|c|}{$\begin{array}{l}\text { Zawartość estrów metylowych kwasów tłuszczowych } \\
\text { Content of fatty acids methyl esters [\%] }\end{array}$} \\
\hline & $\begin{array}{l}\text { Ekstrakt } 1 \\
\text { Extract } 1\end{array}$ & $\begin{array}{c}\text { Ekstrakt } 2 \\
\text { Extract } 2\end{array}$ & $\begin{array}{c}\text { Ekstrakt } 3 \\
\text { Extract } 3\end{array}$ & $\begin{array}{c}\text { Ekstrakt } 4 \\
\text { Extract } 4\end{array}$ & $\begin{array}{r}\text { Ekstrakt } 5 \\
\text { Extract } 5\end{array}$ \\
\hline $\begin{array}{l}\text { Kwas kapronowy, C6:0 } \\
\text { Caproic acid, C6:0 }\end{array}$ & 0,18 & 0,18 & 0,19 & 0,22 & 0,21 \\
\hline $\begin{array}{l}\text { Kwas kaprylowy, C8:0 } \\
\text { Caprylic acid, C8:0 }\end{array}$ & 0,05 & 0,04 & 0,04 & 0,07 & 0,04 \\
\hline $\begin{array}{l}\text { Kwas kaprynowy, C10:0 } \\
\text { Capric acid, C10:0 }\end{array}$ & 0,05 & 0,04 & 0,04 & 0,05 & 0,06 \\
\hline $\begin{array}{l}\text { Kwas laurynowy, C12:0 } \\
\text { Lauric acid, C12:0 }\end{array}$ & 0,06 & 0,06 & 0,08 & 0,06 & 0,10 \\
\hline $\begin{array}{l}\text { Kwas mirystynowy, C14:0 } \\
\text { Myristic acid, C14:0 }\end{array}$ & 0,48 & 0,49 & 0,56 & 0,48 & 0,54 \\
\hline $\begin{array}{l}\text { Kwas pentadekanowy, C15:0 } \\
\text { Pentadecanoic acid, C15:0 }\end{array}$ & 0,05 & 0,05 & 0,05 & 0,06 & 0,06 \\
\hline $\begin{array}{l}\text { Kwas palmitynowy, C16:0 } \\
\text { Palmitic acid, C16:0 }\end{array}$ & 27,41 & 28,42 & 26,55 & 28,42 & 28,06 \\
\hline $\begin{array}{l}\text { Kwas oleopalmitynowy, C16:1,n-7 } \\
\text { Oleopalmitic acid, C16:1, n-7 }\end{array}$ & 0,13 & 0,13 & 0,15 & 0,14 & 0,16 \\
\hline $\begin{array}{l}\text { Kwas margarynowy, C17:0 } \\
\text { Margaric acid, C17:0 }\end{array}$ & 0,21 & 0,20 & 0,16 & 0,16 & 0,19 \\
\hline $\begin{array}{l}\text { Kwas stearynowy, C18:0 } \\
\text { Stearic acid, C18:0 }\end{array}$ & 2,73 & 3,41 & 2,97 & 3,01 & 1,95 \\
\hline $\begin{array}{l}\text { Kwas oleinowy, C18:1,n-9 } \\
\text { Oleic acid, C18:1,n-9 }\end{array}$ & 3,45 & 5,47 & 5,64 & 3,31 & 2,42 \\
\hline
\end{tabular}




\begin{tabular}{|c|c|c|c|c|c|}
\hline $\begin{array}{c}\text { Kwas linolowy, C18:2, n-6 } \\
\text { Linoleic acid, C18:2,n-6 }\end{array}$ & 23,25 & 24,86 & 26,44 & 23,64 & 24,45 \\
\hline $\begin{array}{l}\text { Kwas arachidowy, C20:0 } \\
\text { Arachidic acid, C20:0 }\end{array}$ & 1,20 & 1,06 & 0,94 & 0,91 & 0,86 \\
\hline $\begin{array}{c}\text { Kwas } \alpha \text {-linolenowy, C18:3, } n-3 \\
\alpha \text {-linolenic acid, C18:3, } n-3\end{array}$ & 37,70 & 33,38 & 34,11 & 37,29 & 38,78 \\
\hline $\begin{array}{c}\text { Kwas heneikozanowy, C21:0 } \\
\text { Heneicosanoic acid, C21:0 }\end{array}$ & 0,15 & 0,13 & 0,11 & 0,14 & 0,11 \\
\hline $\begin{array}{c}\text { Kwas eikozadienowy, C20:2, } n-6 \\
\text { Eicosadienoic acid, C20:2, } n-6\end{array}$ & 0,08 & 0,07 & 0,07 & 0,06 & 0,05 \\
\hline $\begin{array}{l}\text { Kwas behenowy, C22:0 } \\
\text { Behenic acid, C22:0 }\end{array}$ & 1,02 & 0,67 & 0,64 & 0,64 & 0,63 \\
\hline $\begin{array}{c}\text { Kwas arachidonowy, C20:4, n-6 } \\
\text { Arachidonic acid, C20:4, n- } 6\end{array}$ & 0,31 & 0,29 & 0,23 & 0,29 & 0,36 \\
\hline $\begin{array}{c}\text { Kwas trikozanowy, C23:0 } \\
\text { Tricosanoic acid, C23:0 }\end{array}$ & 0,11 & 0,10 & 0,07 & 0,06 & 0,06 \\
\hline $\begin{array}{c}\text { Kwas eikozapentaenowy, C20:5, } n-3 \\
\text { Eicosapentaenoic acid, C20:5, } n-3\end{array}$ & 0,01 & 0,00 & 0,01 & 0,00 & 0,04 \\
\hline $\begin{array}{c}\text { Kwas lignocerowy, C24:0 } \\
\text { Lignoceric acid, C24:0 }\end{array}$ & 1,37 & 0,96 & 0,94 & 0,97 & 0,88 \\
\hline
\end{tabular}

Na podstawie wyników obliczono zawartość SFA, UFA, MUFA, PUFA, sumę kwasów n-3 i n-6 (tab. 3). Zdecydowaną większość (64,7 $\div 66,7 \%$ ) stanowiły kwasy jedno- $\mathrm{i}$ wielonienasycone. We wszystkich ekstraktach kwasy thuszczowe $n-3$ dominowały nad $n-6$. Najwyższą wartością stosunku nienasyconych kwasów tłuszczowych do kwasów nasyconych cechował się ekstrakt 3., do którego otrzymania zastosowano najwyższe ciśnienie i krótki czas procesu ekstrakcji. Zawartość UFA kształtowała się na poziomie $64,7 \div 66,7 \%$ wszystkich wyizolowanych kwasów thuszczowych. Największą zawartością nienasyconych kwasów tłuszczowych cechowały się ekstrakty 3. i 5. (tab. 3). Duża różnica zawartości UFA pomiędzy ekstraktem 4. i 5. (1,51\%) spowodowana była najprawdopodobniej wydłużonym czasem ekstrakcji podczas uzyskiwania próby 4. Można zatem przypuszczać, że wydłużony czas procesu wpływa na zwiększone wymywanie nasyconych kwasów tłuszczowych. Największą zawartość PUFA stwierdzono w ekstrakcie 5., a najmniejszą - w 2. Z kolei ekstrakt 3. cechował się największą zawartością sumy nienasyconych kwasów tłuszczowych, natomiast w przypadku wielonienasyconych kwasów tłuszczowych to ekstrakt 5. zawierał ich najwięcej (tab. 3).

Zastosowanie ekstrakcji płynami nadkrytycznymi i modulacja głównymi parametrami ekstrakcji: temperaturą $\left(50 \div 60{ }^{\circ} \mathrm{C}\right)$, ciśnieniem $(150 \div 250$ barów) i czasem procesu $(130 \div 290 \mathrm{~min})$ pozwoliła na uzyskanie ekstraktów cechujących się różnym 
Tabela 3. Wartości parametrów charakteryzujących profil kwasów tłuszczowych ekstraktów z suszu liści pokrzywy

Table 3. Values of parameters characterising fatty acid profile of extracts of dried nettle leaves

\begin{tabular}{||c|c|c|c|c|c|c|c|c||}
\hline $\begin{array}{c}\text { Ekstrakt } \\
\text { Extract }\end{array}$ & $\begin{array}{c}\text { SFA } \\
{[\%]}\end{array}$ & $\begin{array}{c}\text { MUFA } \\
{[\%]}\end{array}$ & $\begin{array}{c}\text { PUFA } \\
{[\%]}\end{array}$ & $\begin{array}{c}\text { Suma } n-6 \\
\text { Total } n-6\end{array}$ & $\begin{array}{c}\text { Suma } n-3 \\
\text { Total } n-3\end{array}$ & $n-6 / n-3$ & UFA [\%] & UFA/SFA \\
\hline 1 & 35,070 & 3,580 & 61,350 & 23,640 & 37,710 & 0,627 & 64,930 & 1,851 \\
\hline 2 & 34,517 & 5,479 & 60,004 & 27,277 & 32,727 & 0,833 & 65,483 & 1,897 \\
\hline 3 & 33,343 & 5,791 & 60,866 & 26,743 & 34,123 & 0,784 & 66,657 & 1,999 \\
\hline 4 & 35,257 & 3,451 & 61,292 & 23,995 & 37,297 & 0,643 & 64,743 & 1,836 \\
\hline 5 & 33,747 & 2,580 & 63,674 & 24,858 & 38,816 & 0,640 & 66,253 & 1,963 \\
\hline
\end{tabular}

Objaśnienia / Explanatory notes:

SFA - kwasy thuszczowe nasycone / saturated fatty acids; MUFA - kwasy thuszczowe jednonienasycone / monounsaturated fatty acids; PUFA - wielonienasycone kwasy thuszczowe / poliunsaturated fatty acids; UFA - kwasy thuszczowe nienasycone / unsaturated fatty acids.

profilem kwasów tłuszczowych. Ekstrakt uzyskany w temp. $60{ }^{\circ} \mathrm{C}$ i przy ciśnieniu 250 barów cechował się największą zawartością wielonienasyconych kwasów thuszczowych w stosunku do kwasów nasyconych $(63,7 \%)$, natomiast w przypadku ekstraktu uzyskanego w temp. $50{ }^{\circ} \mathrm{C}$ i przy ciśnieniu 150 barów zawartość PUFA kształtowała się na poziomie $60 \%$. Można zatem przypuszczać, że w celu wydajnego pozyskiwania z liści pokrzywy wielonienasyconych kwasów thuszczowych metodą ekstrakcji SFE- $\mathrm{CO}_{2} \mathrm{z}$ dodatkiem współrozpuszczalnika w postaci etanolu korzystne jest prowadzenie procesu $\mathrm{W}$ wyższej temperaturze $\left(60^{\circ} \mathrm{C}\right)$ i przy wyższym ciśnieniu (250 barów). Zbyt długi czas (290 min) prowadzenia procesu ekstrakcji próby 4. w porównaniu ze 130 min ekstrahowania próby 2 . spowodował natomiast zmniejszenie stosunku UFA do SFA z 66,7 \% do 64,7 \%. Może to być spowodowane rozpadem i utlenianiem się nienasyconych kwasów tłuszczowych. Straty kwasu eikozapentaenowego (EPA) zaobserwowane w ekstraktach 2. i 4. prawdopodobnie były spowodowane przeprowadzeniem procesu przy zbyt niskim ciśnieniu 150 barów (ekstrakt 2) lub w zbyt długim czasie wymywania 290 min (ekstrakt 4).

Podsumowując, można powiedzieć, że proces ekstrakcji dwutlenkiem węgla w warunkach nadkrytycznych należy uznać za skuteczną metodę pozyskiwania wielonienasyconych kwasów tłuszczowych z liści pokrzywy zwyczajnej pod warunkiem zastosowania odpowiednich parametrów procesu.

\section{Wnioski}

1. Wzrost ciśnienia ze 150 do 250 barów i temperatury z 50 do $60{ }^{\circ} \mathrm{C}$ podczas procesu ekstrakcji liści pokrzywy przy udziale SFE- $\mathrm{CO}_{2} \mathrm{z}$ dodatkiem współrozpuszczalnika w postaci etanolu powoduje zwiększenie o 3,7 \% wymycia wielonienasyconych kwasów tłuszczowych w stosunku do kwasów nasyconych. 
2. Wydłużenie procesu ze 130 do 290 min skutkuje obniżeniem o 2,4 \% wartości stosunku wielonienasyconych kwasów tłuszczowych do nasyconych kwasów thuszczowych w otrzymanych ekstraktach.

3. Ekstrakty z liści pokrzywy zwyczajnej o najwyższej jakości (bogate w kwasy thuszczowe wielonienasycone) uzyskuje się podczas procesu ekstrakcji w temp. $50{ }^{\circ} \mathrm{C}$, przy ciśnieniu 250 barów i w ciągu $130 \mathrm{~min}$.

\section{Literatura}

[1] De Carvalho C.C.C.R., Caramujo M.J.: The various roles of fatty acids. Molecules, 2018, 23 (10), \#2583.

[2] Durović S., Pawlić B., Sorgić S., Popov S., Savić S., Petronijević M., Radojković M., Cvetanović A., Zeković Z.: Chemical composition of stinging nettle leaves obtained by different analytical approaches. J. Func. Food, 2017, 32, 18-26.

[3] Durović S., Zeković Z., Sorgić S., Popov S., Vujanović M., Radojković M.: Fatty acid profile of stinging nattle leaves: Application of modern analytical procedures for sample preparation and analysis. Analytical Methods, 2018, 9, 1080-1087.

[4] Esposito S., Bianco A., Russo R., Di Maro A., Isernia C., Pedone P.V.: Therapeutic perspectives of molecules from Urtica dioica extracts for cancer treatment. Molecules, 2019, 24 (15), \#2753.

[5] Gugała M., Zarzecka K., Sikorska A.: Prozdrowotne właściwości oleju rzepakowego. Postępy Fitoterapii, 2014, 2, 100-103.

[6] Jakubczyk K., Janda K., Szkyrpan S., Gutowska I., Wolska J.: Pokrzywa zwyczajna (Urtica dioica L.) - charakterystyka botaniczna, biochemiczna i właściwości prozdrowotne. Pomeranian J. Life Sci., 2015, 61 (2), 191-198.

[7] Janiszewska E., Witrowska-Rajchert D.: Ekstrakcja nadkrytyczna w przemyśle spożywczym. Żywność. Nauka. Technologia. Jakość., 2005, 4 (45), 5-16.

[8] Joshi B.C., Mukhija M., Kalia A.N.: Pharmacognostical review of Urtica dioica L. Int. J. Green Pharm., 2014, 8 (4), 201-209.

[9] Kregiel D., Pawlikowska E., Antolak H.: Urtica ssp.: Ordinary plants with extraordinary properties. Molecules, 2018, 23 (7), \#1664.

[10] Lauzon H., Morgeirsson B., Sveinsdóttir K., Gudjonsdottir M., Karlsdottir M., Marinsdottir E.: Overview of fish quality research. Impact of fish handling, processing, storage and logistics on fish quality deterioration. Skýrsla Matís, 2010, 39 (10), 1-73.

[11] Ohlhorst S.D., Russel R., Bier D., Klurfeld D.M., Li Z., Mein J.R., Milner J., Ross A.C., Stover P., Konopka E.: Nutrition research to affect food and a healthy lifespan. Advances in Nutrition, 2013, 4, 579-584.

[12] Pagare S., Bhatia M., Tripathi N., Pagare S., Bansal Y.K.: Secondary metabolites of plants and their role: Overview. Curr. Trends Biotechnol. Pharm., 2015, 9, 293-304.

[13] Pasquale M.: The essentials of essential fatty acids. J. Diet. Suppl., 2009, 6 (2), 143-161.

[14] Refajlovska V., Kavrakovski Z., Klopcevska J., Srbinoska M.: Determination of protein and mineral contents in stinging nettle. Quality of Life, 2013, 4 (1-2), 26-30.

[15] Roche H.M.: Unsaturated fatty acids. Proc. Nutr. Soc., 1999, 58, 397-401.

[16] Rui H.L.: Dietary bioactive compounds and their health implications. J. Food Sci., 2013, 78, 18-25.

[17] Sapkale G.N., Patil S.M., Surwase U.S., Bhatbhage P.K.: Supercritical fluid extraction. Int. J. Chem. Sci., 2010, 8 (2), 729-743. 
[18] Sasidharan S., Chen Y., Saravanan D., Sundram K.M., Yoga Latha L.: Extraction, isolation and characterization of bioactive compounds from plants extracts. Afr. J. Trad. Compl. Altern. Med., 2011, 8 (1), 1-10.

[19] Sharif K.M., Rahman M.M., Azmir J., Mohamed A., Jahurul M.H.A., Sahena F., Zaidul I.S.M.: Experimental design of supercritical fluid extraction - A review. J. Food Eng., 2014, 124, 105-116.

[20] Twinning C., Brenna J.T., Hairston N., Flecker A.S.: Highly unsaturated fatty acids in nature: What we know and what we need to learn. Oikos, 2016, 125, 749-760.

[21] Wroniak M., Rękas A., Piekarniak I.: Wpływ rodzaju opakowania i warunków przechowywania na wybrane cechy jakości oleju rzepakowego tłoczonego na zimno. Żywność. Nauka. Technologia. Jakość., 2015, 2 (99), 62-78.

\title{
DETERMINATION OF THE PROFILE OF FATTY ACIDS IN EXTRACTS OBTAINED BY SUPERCRITICAL CARBON DIOXIDE EXTRACTION FROM STINGING NETTLE LEAVES (URTICA DIOICA L.)
}

\author{
S u m m a r y
}

Ecological plant extracts, that are rich in biologically active substances, are a valuable raw material for the food industry, thus new sources thereof are constantly searched for. Special attention is paid to common plants that are resistant to difficult weather conditions, easily available and inexpensive to grow. This type of plants includes stinging nettle (Urtica dioica L.). The objective of the research study was to determine the profile of fatty acids contained in stinging nettle leaves, in extracts obtained by an extraction method using supercritical carbon dioxide with the addition of ethanol. There were obtained 5 extracts that differed in the method of obtaining them and in the process parameters - time, pressure and temperature. A GC-MS method was applied to determine the fatty acid profile. To identify the compounds, mass spectra were compared with the NIST 11 library as were retention times with a certified reference material. In all the extracts the content of unsaturated fatty acids was higher than that of saturated fatty acids. The research study showed that the increase in temperature and pressure resulted in washing out a greater amount of desirable unsaturated fatty acids. The highest content of unsaturated fatty acids was reported in the extract obtained at a temperature of $50{ }^{\circ} \mathrm{C}$ and a pressure of 250 bars. In the extracts obtained using a low pressure and an extended extraction time was not identified eicosapentaenoic acid, which was present in the remaining samples.

Key words: stinging nettle, supercritical carbon dioxide extraction, gas chromatography, profile of fatty acids 